\title{
Guru Berkarakter Untuk Pendidikan Karakter
}

\author{
Wiwin Luqna Hunaida \\ Dosen Fakultas Tarbiyah IAIN Sunan Ampel Surabaya DPK di STAI Al Khoziny Sidoarjo
}

\begin{abstract}
A teacher is one of the figures who will serve as role models in their behaviors, actions and saying by the students either in the classroom, school and even outside the school environment or in society. He/She will always be noticed and become a spotlight by his/her surrounding commu- nities. Teachers not only have a job to teach, but also have a duty to educate their country. It means that their noble task is not only to educate children intellectually an sich, but also to instill the noble values as the role models and guidance in livelihoods, whether it is derived from the religious, customary and cultural values, so that they grow as the next generation with high quality of personality and character. To realize these expecta-tions, the teacher must have intellectual abilities and good emotional and spiritual character.
\end{abstract}

Kata Kunci: Pendidikan karakter; guru berkarakter; siswa berkarakter

\section{A. Pendahuluan}

Di Indonesia, "Pendidikan karakter" bukanlah hal baru,begitupun dalam sistem pendidikan nasional Indonesia. Namun, dunia pendidikan kini kem- bali diramaikan dengan kebijakan Kementerian Pendidikan Nasional yang mengusung pendidikan karakter lima tahun ke depan melalui Rencana Strategis Kementerian Pendidikan Nasional 2010-2014. Betapa tidak,Ketika bangsa Indonesia bersepakat untuk memproklamasikan kemerdekaannya pada tanggal 17 Agustus 1945, para bapak pendiri negeri ini menyadari bah- wa paling tidak ada tiga tantangan besar yang harus dihadapi, pertama, adalah mendirikan negara yang bersatu dan berdaulat, kedua, adalah mem- bangun bangsa, dan ketiga adalah membangun karakter. Ketiga hal tersebut secara jelas tampak dalam konsep negara bangsa (nation-state) dan pemba- ngunan karakter bangsa (nation and character building). Pada imple-mentasinya kemudian upaya mendirikan negara relatif lebih cepat diban- dingkan dengan upaya untuk membangun bangsa dan membangun karakter. Kedua hal terakhir ini terbukti harus diupayakan terus menerus sepanjang sejarah kehidupan kebangsaan Indonesia.

Presiden pertama Republik Indonesia, Bung Karno, menegaskan: "Bangsa ini harus dibangun dengan mendahulukan pembangunan karakter (charac- ter building) karena character building inilah yang akan membuat Indonesia menjadi bangsa yang besar, maju dan jaya, serta bermartabat. Kalau cha- racter building ini tidak dilakukan, maka bangsa Indonesia akan menjadi bangsa kuli"

Sementara itu, pada Hari Pendidikan Nasional tanggal 2 Mei 2011, Moham- mad Nuh, Menteri Pendidikan Nasional telah mencanangkan tema peri- ngatan Pendidikan Karakter sebagai pilar Kebangkitan Bangsa dengan subtema Raih Prestasi Junjung Tinggi Budi Pekerti. Dalam kesempatan tersebut, Mendiknas menegaskan:"Di sinilah mengapa pendidikan berbasis karakter dengan segala dimensi dan variasinya menjadi penting dan mutlak. Karakter yang ingin kita bangun bukan hanya kesantunan, tetapi secara bersamaan kita bangun karakter yang mampu menumbuhkan kepenasaran intelektual sebagai modal untuk membangun kreativitas dan daya inovasi.

Di dalam Undang-undang Nomor 20 Tahun 2003 tentang Sistem Pendi- dikan Nasional Pasal 3 menyatakan bahwa: "Pendidikan Nasional berfungsi mengembangkan 
Konfrontasi: Jurnal Kultur, Ekonomi dan Perubahan Sosial, 4 (1) Januari 2017, 63-78

P-ISSN: 1410-881X (Print)

Wiwin Luqna Hunaida, Guru Berkarakter Untuk Pendidikan Karakter

DOI: -

http://www.konfrontasi.net/index.php/konfrontasi2

kemampuan dan membentuk watak serta peradaban bangsa -yang bermartabat dalam rangka mencerdaskan kehidupan bangsa, bertujuan untuk berkembangnya potensi peserta didik agar menjadi manusia yang beriman dan bertaqwa kepada Tuhan Yang Maha Esa, berakhlak mulia, sehat, berilmu, cakap, kreatif, mandiri, dan menjadi warga yang demokratis serta bertanggung jawab."

Akhlak mulia merupakan aspek penting dalam pendidikan. Bahkan suatu Negara yang berkarakter juga ditentukan oleh tingkat akhlak bangsanya. Dalam ayat tersebut dinyatakan “.... membentuk watak... ", pembentukan watak ini dapat dikatakan sebagai upaya membentuk karakter. Pembangunan karakter merupakan tujuan luar biasa dari system pendidikan yang benar.

Slamet Imam Santoso mengemukakan bahwa tujuan tiap pendidikan yang murni adalah menyusun harga diri yang kukuh-kuat dalam jiwa pelajar, supaya mereka kelak dapat bertahan dalam masyarakat. Di bagian lain dikemukakan bahwa pendidikan bertugas mengembangkan potensi individu semaksimal mungkin dalam batas-batas kemampuannya, sehingga terben- tuk manusia yang pandai, terampil, jujur, tahu kemampuan dan batas ke- mampuannya, serta mempunyai kehormatan diri. Dengan demikian, pem- binaan watak merupakan tugas utama pendidikan.

Di Indonesia, pelaksanaan pendidikan karakter saat ini memang dirasakan mendesak. Gambaran situasi masyarakat bahkan situasi dunia pendidikan di Indonesia menjadi motivasi pokok pengarus-utamaan (mainstreaming) implementasi pendidikan karakter di Indonesia. Pendidikan karakter dirasakan amat perlu pengembangannya bila mengingat makin meningkatnya tawuran antar pelajar/ mahasiswa, serta bentuk-bentuk kenakalan remaja lainnya yang tidak hanya terjadi di kota-kota besar akan tetapi sudah merambah ke pelosok desa, pemerasan/kekerasan, kecenderungan dominasi senior terhadap yunior, fenomena suporter bonek, penggunaan narkoba, dan lain-lain. Bahkan yang paling memprihatinkan, keinginan untuk mem- bangun sifat jujur pada anak-anak dan mahasiswa melalui kantin kejujuran di sejumlah sekolah dan perguruan tinggi, banyak yang gagal, banyak usaha Kantin Kejujuran yang bangkrut karena belum bangkitnya sikap jujur pada para peserta didik.Selain itu kasuskasus tidak disiplin, bertindak curang baik mencontek, mencontoh pekerjaan teman dan sebagainyapun sering terjadi.

Mengingat begitu pentingnya karakter dalam membangun sumber daya manusia yang tangguh untuk keberlangsungan kehidupan, maka diperlukan kepedulian oleh berbagai pihak baik pemerintah, masyarakat, keluarga maupun sekolah. Kondisi ini akan terbangun jika semua pihak memiliki kesadaran bersama dalam membangun watak, karakter atau akhlak mulia generasi muda kita, bahwa hal ini menjadi tanggung jawab bersama antara orang tua, guru, tokoh masyarakat setempat dan para petinggi negeri ini.

\section{B. GambaranPendidikan Karakter \\ 1. Apa Pendidikan Karakter itu?}

Ada beberapa penamaan nomenklatur untuk merujuk kepada kajian pembentukan karakter peserta didik, tergantung kepada aspek pene- kanannya. Di antaranya yang umum dikenal ialah: Pendidikan Moral, Pendidikan Nilai, Pendidikan Relijius, Pendidikan Budi Pekerti, dan Pendidikan Karakter itu sendiri.

Menurut Kamus Besar Bahasa Indonesia karakter merupakan sifat- sifat kejiwaan, akhlak atau budi pekerti yang membedakan seseorang dengan yang lain. Dengan demikian karakter adalah nilai-nilai yang unik-baik yang terpatri dalam diri dan terejawantahkan dalam peri- laku 
Konfrontasi: Jurnal Kultur, Ekonomi dan Perubahan Sosial, 4 (1) Januari 2017, 63-78

P-ISSN: 1410-881X (Print)

Wiwin Luqna Hunaida, Guru Berkarakter Untuk Pendidikan Karakter

DOI: -

http://www.konfrontasi.net/index.php/konfrontasi2

seseorang yang menjadi ciri dan membedakan ciri pribadi, ciri etis dan komplek-sitas mental dari seseorang atau suatu kelompok atau suatu bangsa.

Menurut Sa'dun Akbar4 bahwa karakter adalah watak, tabiat, akhlak, adab, atau ciri kepribadian seseorang yang terbentuk dari hasil inter- nalisasi berbagai nilai kebajikan (virtues) yang diyakini dan digunakan sebagai landasan berpikir, bersikap, dan bertindak. Kebajikan bersumber dari sejumlah nilai, moral, dan norma, yang diyakini kebe- narannya yang terwujud dalam hubungan-hubungan yang mem- bangun interaksi antara manusia dengan tuhannya, sesama manusia, lingkungan hidup-nya, bangsa dan negaranya, dan dengan dirinya sendiri.

Dengan demikian karakter dapat dimaknai sebagai cara berpikir dan berprilaku yang khas dari tiap individu untuk hidup dan bekerjasama, baik dalam lingkup keluarga, masyarakat, bangsa dan negara. Indi- vidu yang berkarakter baik adalah individu yang dapat membuat keputusan dan siap mempertanggungjawabkan setiap akibat dari keputusannya. Karakter dapat dianggap sebagai nilai-nilai perilaku manusia yang berhubungan dengan Tuhan Yang Maha Esa, diri sendiri, sesama manu-sia, lingkungan dan kebangsaan yang terwujud dalam pikiran, sikap, perasaan, perkataan,dan perbuatan sehari-hari berdasarkan norma-norma agama, hukum, tata krama, budaya dan adat istiadat setempat.

Menurut Helen G. Douglas dalam Muchlas samani5: Character isn't inherited. One builds its daily by the way one thinks and acts, thought by thought, action by action. Karakter tidak diwariskan, tetapi sesuatu yang dibangun secara berkesinambungan hari demi hari melalui pikiran dan perbuatan, pikiran demi pikiran, tindakan demi tindakan. Dus, pembentukan karakter sebagai identitas diri atau jati diri seseorang membutuhkan berbagai upaya. Karakter memang tidak diwariskan akan tetapi karakter banyak dipengaruhi oleh here- ditas dan lingkungan tempat seseorang dibesarkan. Perilaku seorang anak sering kali tidak jauh dari perilaku ayah dan ibunya. Dalam bahasa Jawa dikenal istilah "Kacang ora ninggal lanjaran" (Pohon kacang panjang tidak pernah meninggalkan kayu atau bambu tempat- nya melilit dan menjalar). Dalam Peribahasa Indonesia kita kenal "buah jatuh tak jauh dari pohonnya". Selain itu lingkungan, baik ling- kungan sosial maupun lingkungan alam ikut serta membentuk karakter. Di lingkungan yang gersang, panas dan tandus, penduduknya cenderung bersifat keras dan berani mati.

Terminologi "karakter" itu sendiri sedikitnya memuat dua hal: values (nilai-nilai) dan kepribadian. Suatu karakter merupakan cerminan dari nilai apa yang melekat dalam sebuah entitas. "Karakter yang baik" pada gilirannya adalah suatu penampakan dari nilai yang baik pula, yang dimiliki oleh orang atau sesuatu, di luar persoalan apakah "baik" sebagai sesuatu yang "asli" ataukah sekadar kamuflase. Dari hal ini, maka kajian pendidikan karakter akan bersentuhan dengan wilayah filsafat moral atau etika yang bersifat universal, seperti keju- juran. Pendidikan karakter sebagai pendidikan nilai menjadikan "upa- ya eksplisit mengajarkan nilainilai, untuk membantu siswa mengem- bangkan disposisi-disposisi guna bertindak dengan caracara yang pasti”. Persoalan baik dan buruk, kebajikan-kebajikan, dan keuta- maan-keutamaan menjadi aspek penting dalam pendidikan karakter semacam ini.

Pengertian karakter menurut Pusat Bahasa Depdiknas adalah "bawa- an, hati, jiwa, kepribadian, budi pekerti, perilaku, personalitas, sifat, tabiat, temperamen, watak". Adapun berkarakter adalah berkepri- badian, berperilaku, bersifat, bertabiat, dan berwatak". Menurut Tadkiroatun Musfiroh,7karakter mengacu kepada serangkaian sikap (attitudes), peri-laku (behaviors), motivasi (motivations), dan kete- rampilan (skills). Karakter berasal dari bahasa Yunani yang berarti "to mark" atau menandai dan memfokuskan bagaimana mengaplikasikan nilai kebaikan dalam bentuk tindakan atau tingkah laku, sehingga orang yang tidak jujur, kejam, 
Konfrontasi: Jurnal Kultur, Ekonomi dan Perubahan Sosial, 4 (1) Januari 2017, 63-78

P-ISSN: 1410-881X (Print)

Wiwin Luqna Hunaida, Guru Berkarakter Untuk Pendidikan Karakter

DOI: -

http://www.konfrontasi.net/index.php/konfrontasi2

rakus dan perilaku jelek lainnya dikatakan orang berkarakter jelek. Sebaliknya, orang yang perilakunya sesuai dengan kaidah moral disebut dengan berkarakter mulia.

Menurut Simon Philips dalam Buku Refleksi Karakter Bangsa8 me- nyatakan bahwa: karakter adalah kumpulan tata nilai yang menuju pada suatu sistem, yang melandasi pemikiran, sikap, dan perilaku yang ditampilkan. Sedangkan Koesoema A Doni,9memahami bahwa karakter sama dengan kepribadian. Kepribadian dianggap sebagai "ciri, atau karakteristik, atau gaya, atau sifat khas dari diri seseorang yang bersumber dari bentukan-bentukan yang diterima dari ling- kungan, misalnya lingkungan keluarga pada masa kecil dan juga bawaan seseorang sejak lahir." Hal yang selaras disampaikan dalam Buku Refleksi Karakter Bangsa, yang mengartikan karakter bangsa sebagai kondisi watak yang merupakan identitas bangsa.

Sementara Winnie10 memahami bahwa istilah karakter diambil dari bahasa Yunani yang berarti 'to mark' (menandai). Istilah ini lebih fokus pada tindakan atau tingkah laku. Ada dua pengertian tentang karakter. Pertama, ia menunjukkan bagaimana seseorang bertingkah laku. Apabila seseorang berperilaku tidak jujur, kejam, atau rakus, tentulah orang tersebut memanifestasikan perilaku buruk. Sebaliknya, apabila seseorang berperilaku jujur, suka menolong, tentulah orang tersebut memanifestasikan karakter mulia. Kedua, istilah karakter erat kaitannya dengan 'personality'. Seseorang baru bisa disebut 'orang yang berkarakter' (a person of character) apabila tingkah laku- nya sesuai kaidah moral. Sedangkan Imam Ghozali menganggap bahwa karakter lebih dekat dengan akhlaq, yaitu spontanitas manusia dalam bersikap, atau melakukan perbuatan yang telah menyatu dalam diri manusia sehingga ketika muncul tidak perlu dipikirkan lagi.

Pendidikan karakter mengajarkan kebiasaan cara berpikir dan peri- laku yang membantu individu untuk hidup dan bekerja bersama sebagai keluarga, masyarakat, dan bernegara dan membantu mereka untuk membuat keputusan yang dapat dipertanggungjawabkan. Se- lanjutnya karakter yang terbangun tersebut diharapkan akan men-dorong setiap manusia untuk mengerjakan segala sesuatu sesuai de- ngan kata hati dan penuh tanggung jawab. Karena bagaimanapun juga, karakter adalah kunci keberhasilan seorang individu. Dari sebuah penelitian di Amerika, 90\% kasus pemecatan disebabkan oleh perilaku buruk seperti tidak bertanggung jawab, tidak jujur, dan hubungan interpersonal yang buruk.

\section{Bagaimana pendidikan karakter yang ideal?}

Pendidikan karakter hendaknya mencakup aspek pembentukan kepri- badian yang memuat dimensi nilai-nilai kebajikan universal dan kesadaran kultural di mana norma-norma kehidupan itu tumbuh dan berkembang. Ringkasnya, pendidikan karakter mampu membuat kesadaran transendental individu, mampu terejawantahkan dalam perilaku yang konstruktif berdasarkan konteks kehidupan di mana ia berada: Memiliki kesadaran global, namun mampu bertindak sesuai konteks lokal.

Mengapa pendidikan belum mampu mengubah perilaku warga bangsa menjadi lebih baik? Mengapa kejujuran, komitmen, keuletan, kerja keras, hingga kesalehan (kesalehan pribadi dan kesalehan sosial) seolah lepas dari persoalan pendidikan? Untuk menjawab pertanyaanpertanyaan tersebut barangkali kita perlu melihat kenyataan, bahwa selama ini sistem pendidikan yang berlaku kurang menekankan pembentukan karakter, tetapi lebih menekankan pengembangan inte- lektual semata, menuntut peserta didiknya untuk menguasai sejumlah kompetensi. 
Konfrontasi: Jurnal Kultur, Ekonomi dan Perubahan Sosial, 4 (1) Januari 2017, 63-78

P-ISSN: 1410-881X (Print)

Wiwin Luqna Hunaida, Guru Berkarakter Untuk Pendidikan Karakter

DOI: -

http://www.konfrontasi.net/index.php/konfrontasi2

Kompetensi memang membuat seseorang dapat melakukan tugasnya dengan baik, namun karakter membuat seseorang bertekad mencapai yang terbaik dan selalu ingin lebih baik.12 Dipihak lain orang-orang dengan kompetensi yang tinggi tanpa disertai karakter yang baik dapat menjadi sumber masalah bagi lingkungannya, karena dengan kompetensinya yang tinggi orang bersangkutan bisa dengan "cerdas" memanfaatkan kompetensinya untuk kepentingannya sendiri dengan merugikan masyarakat luas. Dengan kata lain, keberhasilan pendidik- an saat ini belum mampu membangun jati diri peserta didiknya sebagai generasi tangguh Indonesia, seperti yang diamanatkan dalam pasal 3 UU No. 20 Tahun 2003 tentang Sistem Pendidikan Nasional.

Terkait dengan pembahasan tulisan ini, maka sekolah seharusnya merupakan salah satu lembaga pendidikan yang strategis, untuk menanamkan dan menumbuhkembangkan akhlak mulia, serta mem- bangun karakter para peserta didik melalui keteladanan para guru yang berkarakter, penegakan kedisiplinan selama di sekolah, pembi- asaan terhadap hal-hal yang positif serta terciptanya suasana yang kondusif, pola hubungan interaksi yang harmonis antara guru dan guru; siswa dengan siswa, maupun antara guru dan siswa serta para tenaga kependidikan lainnya. Disamping itu, pihak sekolah pula seharusnya menjalin hubungan yang sinergis dengan orang tua siswa dan masyarakat sekitarnya. Kesemuanya ini dimaksudkan agar peserta didik dalam segala ucapan, sikap dan prilakunya mencermin- kan karakter yang baik dan kuat.

Untuk mewujudkan cita-cita tersebut memerlukan kerja keras dari guru yang memiliki makna "digugu dan ditiru" (dipercaya dan dicontoh) dalam penampilannya seharusnya memiliki sifat-sifat yang dapat membawa peserta didiknya ke arah pembentukan karakter yang kuat, serta harus memiliki komitmen dalam melaksanakan pendidikan secara holistik yang berpusat pada potensi dan kebutuhan peserta didik.

\section{Strategi Pendidikan Karakter}

Guru adalah manusia yang paling tepat dan selalu mempunyai kesem- patan untuk melakukan perubahan perilaku dan mindset siswanya, baik secara gradual maupun secara radikal melalui aktivitas pendi- dikan. Guru diamanatkan bukan hanya oleh orang tua siswa saja, akan tetapi oleh Undang-undang untuk melakukan upaya-upaya yang terbaik bagi perkembangan kognitif, afektif dan psikomotorik peserta didiknya. Ditangan gurulah harapan perubahan tingkah-laku anak manusia ke arah yang lebih baik dialamatkan.

Membentuk karakter bukanlah sekedar mengajarkan kepribadian, karena antara kepribdian dan karakter tidaklah sama. Kepribadian adalah tingkah laku atau perangai manusia sebagai hasil bentukan dan sangat dipengaruhi oleh lingkungan. Sedangkan karakter adalah watak dasar yang berada di dalam diri setiap manusia sejak mereka dilahirkan. Menurut J.Drost, SJ,13 Karakter itu bersifat original, ber- ada di dalam diri. Seseorang yang berkarakter adalah seseorang yang berkepribadian. Bagi orang yang berkarakter berlaku: perlakuan orang lain seperti engkau ingin diperlakukan oleh orang lain.

Berbeda dengan orang yang berkepribadian, dia seringkali ingin diperlakukan oleh orang lain, tetapi dia sendiri tidak ingin memper- lakukan orang lain secara istemewa. Jadi jelas, bahwa orang yang bekepribadian belum tentu orang yang berkarakter. Sebab kepriba- dian adalah hasil polesan, sedangkan karakter adalah sifat dasar manusia yang cenderung ingin selalu berbuat baik dan menyukai kebaikan.

Strategi pendidikan karakter yang paling "sederhana" adalah:

1) Melalui keteladanan 
Konfrontasi: Jurnal Kultur, Ekonomi dan Perubahan Sosial, 4 (1) Januari 2017, 63-78

P-ISSN: 1410-881X (Print)

Wiwin Luqna Hunaida, Guru Berkarakter Untuk Pendidikan Karakter

DOI: -

http://www.konfrontasi.net/index.php/konfrontasi2

Allah SWT dalam mendidik manusia menggunakan contoh atau teladan sebagai model terbaik agar mudah diserap dan diterapkan oleh manusia. Teladan itu diperankan oleh para Nabi atau Rasul, sebagaimana firman-Nya dalam QS. Al Mumtahanah (60): 6: "Sesungguhnya pada mereka itu (Ibrahim dann umatnya) adan teladan yang baik bagimu: (yaitu) bagi orang-orang yang mengharap (pahala) Allah dan (keselamatan pada) Hari Kemudian. Dan barangsiapa yang berpaling, maka sesungguhnya Allah Dialah yang Maha Kaya lagi Maha Terpuji”. Dan dalam QS. Al Ahzab (33): 21 Allah berfirman: " Sesungguhnya telah ada pada (diri) Rasulullah itu suri tauladan yang baik bagimu (yaitu) bagi bagi orang yang mengharapkan (rahmat) Allah dan (kedatangan) hari kiamat dan dia banyak menyebut Allah".

Begitu pentingnya keteladan sehingga Allah menggunakan pende- katan dalam mendidik hambanya melalui model yang harus dan layak dicontoh. Oleh karena itu dapat dikatakan bahwa ketela- danan merupakan strategi pendidikan yang ampuh. Dalam ling- kungan keluarga misalnya, orang tua sebagai pendidik pertama dan utama bagi anak-anaknya, maka harus menjadi teladan yang bagi anak-anaknya. Orang tua harus menjadi figur ideal bagi anak- anak dan harus menjadi panutan yang bisa mereka andalkan dalam mengarungi kehidupan ini. Jika orang tua menginginkan anak-anaknya rajin beribadah maka orang tua harus rajin ber- ibadah pula, sehingga seluruh aktivitasnya itu akan terlihat oleh anak-anak. Keteladan dapat dilakukan kapan saja dan dimana saja, setiap saat dan sepanjang waktu, karena metode ini merupakan metode termurah dan tidak memerlukan tempat tertentu.

Keteladanan memiliki kontribusi yang sangat besar dalam mendi- dik karakter serta menanamkan dan menumbuhkan akhlak mulia. Keteladan guru di sekolah dalam berbagai aktivitasnya akan men- jadi cerminan siswanya. Keteladan lebih mengedepankan aspek perilaku dalam bentuk tindakan nyata daripada sekedar bicara tanpa aksi. Apalagi bila didukung oleh suasana yang memung- kinkan siswa melakukannya. Orang-orang yang bisa dijadikan tela- dan adalah orang-orang yang kata-katanya sesuai dengan perbuat- annya. Contoh ketika guru menasehati agar siswa-siswanya tidak menyontek,bisa dipastikan ketika dia dulu menjadi siswa atau mahasiswa, dia tidak pernah menyontek. Guru-guru yang melarang siswa-siswanya tawuran adalah guru-guru yang ketika masih menempuh pendidikan tidak pernah tawuran. Pendidikan karakter baru akan mengenai sasaran bila dicontohkan, bukan sekedar diajarkan. Perilaku baik yang dipraktikkan guru dihadapan murid- muridnya, akan dicontoh oleh para muridnya sehingga menjadi kebiasaan.Oleh karena itu sosok guru yang idealnya bisa diteladani seluruh aspek kepribadiannya akan menjadi idola yang KEREN:

- Kuat karakternya dan tangguh kepribadiannya

- Etos kerjanya tinggi dan penuh semangat

- Ramah dan senantiasa diliputi kasih sayang

- Egaliter sikapnya, menganggap semua manusia sama dan sederajat

- Nastiti, cermat bertindak dan selalu berhati-hati dalam tutur katanya.

Inilah sosok guru yang berjiwa besar, guru yang benar-benar dapat "digugu" dan "ditiru". Guru yang dapat diteladani hakekatnya ada- lah guru para anak didiknya sepanjang hayat mereka, karena kete- ladanannya akan diteruskan kepada generasi sesudah mereka dan seterusnya.

Keteladanan adalah kunci keberhasilan, termasuk keberhasilan seorang guru dalam mendidik anak didiknya. Contoh dan ketela- danannya lebih bermakna daripada seribu perintah dan larangan. Syair Arab mengatakan: "Qawul ul-hal afshah min lisani almaqal" (keteladanan lebih fasih daripada perkataan)16 
Konfrontasi: Jurnal Kultur, Ekonomi dan Perubahan Sosial, 4 (1) Januari 2017, 63-78

P-ISSN: 1410-881X (Print)

Wiwin Luqna Hunaida, Guru Berkarakter Untuk Pendidikan Karakter

DOI: -

http://www.konfrontasi.net/index.php/konfrontasi2

2) Penegakan kedisiplinan

Disiplin pada hakekatnya adalah suatu ketaatan yang sungguh- sungguh yang didukung oleh kesadran untuk menunaikan tugas kewajiban serta berprilaku sebagaimana mestinya menurut aturan- aturan yang seharusnya berlaku di dalam suatu lingkungan tertentu. Realisasinya harus terlihat dalam perbuatan atau tingkah laku yang nyata, yaitu perbuatan tingkah laku yang sesuai dengan aturan atau tata kelakuan yang semestinya.17

Kedisiplinan menjadi alat yang ampuh dalam mendidik karakter. Banyak orang sukses karena menegakkankedisiplinan. Sebaliknya, banyak upaya membangun sesuatu tidak berhasil karena kurang atau tidak disiplin. Banyak agenda yang telah ditetapkan tidak dapat berjalan karena kurang disiplin. Kurangnya disiplin dapat berakibat melemahnya motivasi seseorang untuk melakukan sesuatu. Motivasi merupakan suatu landasan psikologis yang sa- ngat penting bagi setiap orang dalam melakukan sesuatu aktivitas. Terlebih aktivitas berupa tugas yang menuntut tanggung jawab yang tinggi.

Banyak cara dalam menegakkan kedisiplinan, terutama di sekolah. Misalnya, guru sebagai teladan harus datang pagi dan tidak ter- lambat. Begitu tiba di sekolah, guru sudah berdiri di depan pintu dan menyambut murid-muridnya yang datang dengan senyuman kelas, pemeriksaan kuku setiap minggu dan sebagainya.

3) Pembiasaan

Dorothy Low Nolte dalam Dryden dan Vos18 menyatakan bahwa anak belajar dari kehidupannya. Jika anak dibesarkan dengan celaan, ia belajar memaki; Jika anak dibesarkan dengan permu- suhan, ia belajar berkelahi; Jika anak dibesarkan dengan ketakutan, ia belajar gelisah; Jika anak dibesarkan dengan dengan rasa iba, ia belajar menyesali diri; Jika anak dibesarkan dengan olok- olokan, is belajar rendah diri; Jika anak dibesarkan dengan iri hati, ia belajar kedengkian; Jika anak dibesarkan dengan dipermalukan, is belajar merasa bersalah; Jika anak dibesarkan dengan dorongan, ia belajar percaya diri; Jika anak dibesarkan dengan toleransi, ia belajar menahan diri; Jika anak dibesarkan dengan pujian, ia belajar menghargai; Jika anak dibesarkan dengan penerimaan, ia belajar mencintai; Jika anak dibesarkan dengan dukungan, ia belajar menyenangi diri; Jika anak dibesarkan dengan pengakuan, is belajar mengenali diri; Jika anak dibesarkan dengan pengakuan, ia belajar mengenali tujuan; Jika anak dibesarkan dengan rasa berbagi, ia belajar kedermawanan; Jika anak dibesarkan dengan kejujuran dan keterbukaan, ia belajar kebenaran dan keadilan; Jika anak dibesarkan dengan rasa aman, ia belajar menaruh keperca- yaan; Jika anak dibesarkan dengan persahabatan, ia belajar mene- mukan cinta dalam kehidupan; Jika anak dibesarkan dengan ketentraman, ia belajar berdamai dengan pikiran.

Ungkapan Dorothy Low Nolte tersebut menggambarkan bahwa anak akan tumbuh sebagaimana lingkungan yang mengajarinya dan lingkungan tersebut merupakan sesuatu yang menjadi kebi- asaan yang dihadapinya setiap hari. Anak memiliki sifat senang meniru. Orang tua merupakan lingkungan terdekat yang selalu mengitarinya dan sekaligus menjadi figur dan idolanya. Bila ia melihat kebiasaan baik dari ayah dan ibunya, maka merekapun akan dengan cepat mencontohnya. Orang tua yang berprilaku buruk juga akan ditiru prilakunya oleh anakanak. Begitupun dengan ucapan kita, anak-anak paling mudah mengikuti kata-kata yang keluar dari mulut kita.

Terbentuknya karakter memerlukan proses yang relatif lama dan terus menerus. Oleh karena itu sejak dini harus kita tanamkan pendidikan karakter pada anak. Pendidikan karanter tidak cukup hanya diajarkan melalui mata pelajaran di kelas, tetapi di sekolah- pun dapat juga menerapkannya melalu pembiasaan. Kegiatan pembiasaan secara spontan dapat dilakukan, 
Konfrontasi: Jurnal Kultur, Ekonomi dan Perubahan Sosial, 4 (1) Januari 2017, 63-78

P-ISSN: 1410-881X (Print)

Wiwin Luqna Hunaida, Guru Berkarakter Untuk Pendidikan Karakter

DOI: -

http://www.konfrontasi.net/index.php/konfrontasi2

misalnya dengan saling mengucapkan salam atau saling menyapa, baik antar teman, antar guru, antara guru dan siswa. Pembiasaan ini diarahkan seba- gai upaya pembudayaan pada aktivitas tertentu sehingga menjadi aktivitas yang terpola atau tersistem.

4) Menciptakan suasana yang kondusif

Pada dasarnya tanggung jawab pendidikan karakter ada pada se- mua pihak yang mengitarinya, mulai dari keluarga, sekolah, ma- syarakat, serta pemerintah. Karena pendidikan karakter telah menjadi kebutuhan bersama, maka dibutuhkan kesadaran bersama untuk mewujudkannya.

Lingkungan dapat dikatakan merupakan proses pembudayaan anak dipengaruhi oleh kondisi yang setiap saat dihadapi dan diala- mi anak. Demikian halnya, menciptakan suasana yang kandusif di sekolah merupakan upaya membangun kultur atau budaya yang memungkinkan untuk membangun karakter. Terutama berkaitan dengan membangun budaya kerja dan belajar di sekolah. Tentunya bukan hanya budaya akademik yang dibangun tetapi juga budaya- budaya yang lain, seperti membangun budaya berprilaku yang dilandasi akhlak mulia.

Sekolah yang membudayakan warganya gemar membaca, tentu akan menumbuhkan suasana kondusif bagi siswanya untuk gemar membaca. Demikian juga, sekolah yang membudayakan warganya untuk disiplin, aman, dan bersih,tentu juga akan memberikan suasana untuk terciptanya karakter yang demikian. Untuk mewu- judkan lingkungan yang kondusif dalam menyelenggarakan pendi- dikan di sekolah terutama dalam menciptakan pendidikan karakter diperlukan peran serta seluruh unsur sekolah baik guru, kepala sekolah, tenaga kependidikan dan seluruh civitas akademika lem- baga pendidikan bersangkutan, selain itu perlu dibangun pula ker- ja sama antara sekolah dengan para orang tua atau wali siswa, ser- ta masyarakat sekitar.

\section{Pentingnya Pendidikan Karakter}

Kita harus mengakui bahwa pendidikan karakter adalah bekal paling penting untuk generasi muda sebuah bangsa yang nanti akan mene- rima tongkat estafet kepemimpinan bangsa ini. Oleh karena itu, pendidikan karakter adalah salah satu jawaban untuk menyeim- bangkan dampak buruk globalisasi yang telah menggilas nilai-nilai tradisional yang telah lama kita sepakati sebagai norma dan tata susila. Oleh sebab itu, pendidikan karakter ini seharusnya menjadi kebutuhan bersama bangsa Indonesia. Artinya, masyarakat juga harus ikut memberikan dukungan penuh terhadap penerapan pendidikan karakter tersebut.

Menurut Hamka Abdul Aziz19 ada dua alasan mendesak diterapkannya pendidikan karakter di semua jenjang pendidikan di Indonesia adalah menyangkut perbaikan kualitas manusia Indonesia dan berkenaan dengan pengelolaan hati (qabun).

Terkait dengan alasan pertamabahwa manusia adalah makhluk Allah yang paling sempurna, dan sebaik-baik penciptaan (dalam termino- logi Al Qur'an disebut fii ahsani taqwim). Bukan itu saja, Allah memuliakan manusia lebih dari Dia "memuliakan" makhlukmakh- luk-Nya yang lain. Ini semua adalah penghargaan dan penghormatan Allah terhadap manusia. Oleh karena itu kemulyaan manusia tidak boleh dihancurkan dengan cara memuaskan nafsu dan memberikan perhatian hanya kepada jasadnya saja, sehingga melupakan pembi- naan "hatinya".

Pendidikan karakter adalah salah satu upaya untuk mempertahankan kemulyaan manusia. Dengan pendidikan karakter kita ingin mem- bangun manusia Indonesia seutuhnya. Dalam artian bukan hanya memberikan pemuasan terhadap kebutuhan jasmaninya saja, akan tetapi juga jiwanya (emosional) dan ruhaninya (spiritualitasnya). 
Konfrontasi: Jurnal Kultur, Ekonomi dan Perubahan Sosial, 4 (1) Januari 2017, 63-78

P-ISSN: 1410-881X (Print)

Wiwin Luqna Hunaida, Guru Berkarakter Untuk Pendidikan Karakter

DOI: -

http://www.konfrontasi.net/index.php/konfrontasi2

Berkenaan dengan alasan kedua bahwa sesungguhnya manusia ber- ada pada kebersihan dan kesucian fitrahnya. Fitrah itulah karakter "original" manusia yang sebenarnya. Jadi pendidikan karakter me- ngembalikan manusia kepada fitrah aslinya yang selama ini tertutupi. Nilai-nilai karakter seperti jujur, adil, tanggung jawab, disiplin, berani karena benar, kerja keras, kasih sayang, cinta pada kedamaian, senang pada keindahan, simpati, empati dan sebagainya adalah fitrah manusia. Jadi, bila guru ingin membentuk karakter siswa-siswanya melalui pendidikan, itu artinya guru berurusan dengan hati manusia.

Persoalannya sekarang adalah yang memahami dan paling mengerti urusan hati itu bukan manusia, tetapi allah SWT sebagaimana dalam firmanNya dalam QS. Huud (11): 5: "Allah mengetahui apa yang mereka sembunyikan dan apa yang mereka larikan, sesungguhnya Allah Maha Mengetahui segala isi hati”. Dalam QS. Al- Hajj (22): 46 juga disebutkan:" ... Karena sesungguhnya bukanlah mata itu yang buta, tetapi yang buta ialah hati yang ada di dalam dada".

Memang kita tidak usah malu untuk mengakui bahwa kita memang tidak memahami benar urusan hati. Akan tetapi berdasarkan ayat- ayat-Nya kita berupaya untuk memenuhi kebutuhan fitrah manusia dengan memandang penting persoalan karakter disamping pengeta- huan dan ketrampilan.

Pendidikan pada esensinya menciptakan perubahan perilaku ke arah yang lebih baik, bukan sekedar perubahan pola pikir. Artinya, kesuk- sesan seseorang dalam belajar bukan hanya ditandai dia menjadi orang pintar atau memiliki sederetan gelar kesarjanaan saja, akan tetapi selain itu yang menjadi tolok ukur adalah bagaimana ilmu yang diperoleh dapat diterapkan dan membuat orang menjadi berubah perilakunya ke arah yang lebih baik dan benar. Setiap jenjang pen- didikan yang kita lalui, sebenarnya memberikan kesempatan kepada kita untuk menjadi lebih baik dan menjadi yang terbaik. Di Sekolah Menengah Pertama harus lebih baik dari pada sewaktu di Sekolah Dasar. Di Sekolah Menengah Atas harus lebih baik dapada sewaktu di Sekolah Menengah Pertama, dan begitu seterusnya.

Ketika seseorang telah menjadi mahasiswa, maka perilakunya harus lebih baik daripada ketika dia sebagai siswa. Mahasiswa adalah putra- putri terbaik bangsa. Oleh karena dari sekian juta lulusan Sekolah Lanjutan Atas (MA, SMA, SMK dan sebagainya), hanya segelintir yang beruntung bisa melanjutkan ke jenjang perguruan tinggi. Akan tetapi, jika setelah menjadi mahasiswa perilaku mereka tidak menjadi lebih baik daripada sewaktu mereka menjadi siswa, misalnya melakukan demonstrasi yang cenderung rusuh dan anarkis, itu artinya ada yang salah. Tinggal dicari dan diurai di mana letak kesalahannya agar segera dapat diperbaiki.

Sesungguhnya Allah telah mengingatkan kepada kita dalam QS. An- Nisaa' (4): 9 Allah berfirman: "Dan hendaklah takut kepada Allah orang-orang yang seandainya meninggalkan dibelakang mereka anak- anak yang lemah, yang mereka khawatir terhadap (kesejahteraan) mereka. Oleh sebab itu hendaklah mereka bertaqwa kepada Allah dan hendaklah mereka mengucapkan perkataan yang benar".

Ayat diatas mengingatkan kepada kita agar tidak mewariskan anak- keturunan yang lemah di belakang hari. Lemah disini bisa berarti miskin jiwanya karena tidak beriman dan bertaqwa kepada Tuhan Yang Maha Esa, tidak berakhlak mulia, tidak suka memelihara sifat- sifat yang baik, anak-anak yang hanya menyusahkan dan membebani orang lain, dan sebagainya. Peringatan ini berlaku umum, termasuk di dalamnya adalah orang tua, guru dan suatu bangsa dan negara. Oleh sebab itu, hendaknya kita semua tidak meninggalkan generasi yang lemah yang akan membuat bangsa dan negara itu hancur karena dipimpin oleh orang-orang yang tidak cakap serta tidak memiliki integritas. 
Konfrontasi: Jurnal Kultur, Ekonomi dan Perubahan Sosial, 4 (1) Januari 2017, 63-78

P-ISSN: 1410-881X (Print)

Wiwin Luqna Hunaida, Guru Berkarakter Untuk Pendidikan Karakter

DOI: -

http://www.konfrontasi.net/index.php/konfrontasi2

Itu sebabnya pendidikan karakter menjadi penting untuk menjawab tantangan di era globalisasi seperti sekarang ini. Jadi dengan kalimat yang sederhana, indikasi keberhasilan pendidikan adalah sejauhmana pendidikan karakter dibangun, sehingga negara akan kuat, bersatu, aman dan damai, serta bila pendidikan menghasilkan orang-orang yang berkarakter tangguh. Untuk mewujudkan tujuan tersebut seha- rusnya pendidikan karakter menjadi tanggung jawab bersama antara pemerintah, sekolah, keluarga dan masyarakat.

\section{Pentingnya Guru Berkarakter 1. Siapa Guru itu?}

Dalam Kamus Bahasa Indonesia: Guru adalah orang yang pekerjaan, mata pencahariannya (profesinya) mengajar. Bila ditilik dari asal katanya, kata guru berasal dari bahasa sansekerta "Gu" yang ber- makna "kegelapan, kejumudan atau kekelaman"; dan "ru" yang ber- arti "melepaskan, menyingkirkan, atau membebaskan". Jadi guru adalah orang yang sanggup menjadi penerang kegelapan yang menye- limuti siswanya. Baik kegelapan intelektualnya maupun kegelapan moralnya.

Guru adalah sosok yang digugu dan ditiru. Digugu artinya diindah- kan atau dipercayai. Sedangkan ditiru artinya dicontoh atau diikuti. Dengan demikian guru adalah sosok manusia yang menjadikan dirinya sebagai teladan bagi orang-orang disekitarnya, ucapan dan tindakannya patut untuk didengar dan dicontoh oleh para siswanya. Karena guru adalah manusi yang berjuang terus menerus secara gradual, untuk membebaskan manusia dari kebodohan yang membuat mereka jauh dari ajaran Tuhan. Dia senantiasa berikhtiar mele- paskan manusia dari kekelaman yang mengungkung, yang membuat prilaku mereka buruk seperti layaknya hewan.

Tidak ada guru, tidak ada pendidikan. Tidak ada pendidikan, tidak ada proses pencerdasan. Tanpa proses pencerdasan yang bermaknan, peradaban manusia akan mandeg. Statemen ini bermakna bahwa proses peradaban dan pemanusiaan akan lumpuh tanpa kehadiran guru dalam mentransformasikan proses pembelajaran anak bangsa.

Jadi guru adalah pendidik profesional dengan tugas utamanya men- didik, mengajar, membimbing, mengarahkan, melatih, menilai dan mengevaluasi peserta didik pada satuan pendidikan tertentu baik pada pendidikan anak usia dini, jalur pendidikan formal, pendidikan dasar, pendidikan menengah (UUGD pasal 1). Sebagaimana tertuang dalam pengertian tersebut bahwa tugas utama guru bukan hanya sekedar mengajar tetapi sekaligus mendidik karakter.

Produk kerja guru menjadi simbol kemajuan peradaban. Mereka merupakan pendidik profesional dengan tugas utama mendidik, mengajar, membimbing, mengarahkan, melatih, menilai dan meng- evaluasi peserta didik pada jalur pendidikan formal. Tuga utama tersebut akan efektif jika guru mamiliki derajat profesionalitas ter- tentu yang tercermin dari kompetensi, kemahiran, kecakapan, atau keterampilan yang memenuhi standar mutu atau norma etik tertentu.

Secara formal, untuk menjadi profesional guru dipersyaratkan meme- nuhi kualifikasi akademik minimum dan bersertifikat pendidik. Gu- ru-guru yang memenuhi kriteria profesional inilah yang akan mampu menjalankan fungsi utamanya secara efektif dan efisien untuk mewujudkan proses pendidikan dan pembelajaran untuk mencapai tujuan pendidikan.20 Dalam konteks ke-Indonesiaan, tujuan pendi- dikan yang dimaksud adalah berkembangnya potensi peserta didik agar menjadi manusia yang beriman dan bertaqwa, berakhlak mulia, sehat, berilmu, cakap, kreatif, mandiri serta menjadi warga negara yang demokratis dan bertanggung jawab. 
Konfrontasi: Jurnal Kultur, Ekonomi dan Perubahan Sosial, 4 (1) Januari 2017, 63-78

P-ISSN: 1410-881X (Print)

Wiwin Luqna Hunaida, Guru Berkarakter Untuk Pendidikan Karakter

DOI: -

http://www.konfrontasi.net/index.php/konfrontasi2

Dari makna yang dikandung dalam sebutannya, jelas guru bukan sekedar profesi yang mendatangkan uang sebagaimana lazimnya se- buah profesi. Bukan pula profesi yang dapat mendatangkan gemerlap dunia kepada yang menjalaninya. Guru adalah profesi dimana seseorang menanamkan nilai-nilai kebajikan kepada para peserta didiknya serta orang-orang yang ada disekitanya, membentuk karakter dan kepribadian mereka. Guru adalah seseorang dibarisan terdepan dalam teladan tutur kata dan tingkah laku, yang dipundaknya mele- kat tugas sangat mulia: menciptakan sebuah generasi yang paripurna.

Menciptakan generasi yang paripurna bukanlah pekerjaan mudah, semudah kita membalikkan telapak tangan kita, akan tetapi hal ini merupakan pekerjaan yang selalu berproses. Seolah-olah dia tidak akan menemukan atau sampai pada titik kesudahan. Hal ini sangat beralasan, karena "nasib" sebuah bangsa atau kamunitas manusia seakan-akan sepenuhnya bergantung pada para guru. Guru menjadi ujung tombak dalam sebuah perubahan. Harapan akan munculnya sebuah generasi yang tangguh bagi sebuah negara dipercaya oleh masyarakat luas akan lahir dari sentuhan tangan para guru.

Lepas dari semua kontroversi yang sering ditimbulkan oleh beberapa oknum guru, kita tidak bisa menafikan peran penting guru dalam kehidupan kita. Penulis sepakat bila dikatakan mereka adalah pelita dalam kegelapan. Kegelapan ilmu dan pengetahuan, serta kekelaman hati dan kejumudan pikiran. Bisa dibayangkan betapa berat tugas guru dan betapa besar perannya. Peran guru adalah kombinasi dari peran orang tua, pendidik, pengajar, pembina, pembimbing, penilai dan pemelihara. Karena itulah, sudah selayaknya kita memberikan apresiasi yang tinggi kepada guru.

\section{Guru Berkarakter MelahirkanSiswa Berkarakter}

Dalam Peraturan Pemerintah Republik Indonesia Nomor 19 Tahun 2005 tentang Standar Nasional Pendidikan, pasal 28 ayat 3, menya- takan bahwa ada empat kompetensi yang harus dimiliki guru sebagai figur sentral dalam proses pendidikan dan peningkatan kecerdasan sebuah bangsa. Keempat kompetensi itu adalah: kompetensi pedago- gik, kompetensi profesional (akademik), kompetensi kepribadian, dan kompetensi sosial. Guru dianggap memiliki kemampuan pedago- gik bila menunjukkan kemampuannya dalam mengajar dan mendi- dik. Lalu guru dianggap mempunyai kemampuan profesional bila ia menguasai materi pelajaran yang menjadi bidang keahliannya. Kom- petensi kepribadian ditunjukkan dengan sikap dan prilaku guru yang baik di hadapan siswa-siswa dan lingkungannya. Sedangkan kompe- tensi sosial diperlihatkan melalui keterlibatan guru dalam kegiatan sosial di masyarakat.

Keempat kompetensi tersebut adalah syarat yang harus dimiliki seorang guru. Setidaknya guru akan senantiasa terus terpacu untuk meningkatkan kompetensinya setiap saat. Sebab hanya dengan upaya seperti itu kita akan mempunyai guru-guru profesional yang berkarakter mulia, yang pada akhirnya akan melahirkan pula murid- murid yang berkarakter mulia.

Karakter mulia berarti individu memiliki pengetahuan tentang poten- si dirinya, yang ditandai dengan nilai-nilai seperti reflektif, percaya diri, rasional, logis, kritis, analitis, kreatif dan inovatif, mandiri, hidup sehat, bertanggung jawab, cinta ilmu, sabar, berhati-hati, rela berkorban, pemberani, dapat dipercaya, jujur, menepati janji, adil, rendah hati, malu berbuat salah, pemaaf, berhati lembut, setia, beker- ja keras, tekun, ulet/gigih, teliti, berinisiatif, berpikir positif, disiplin, antisipatif, inisiatif, visioner, bersahaja, bersemangat, dinamis, hemat/efisien, menghargai waktu, pengabdian/dedikatif, pengen- dalian diri, produktif, ramah, cinta keindahan (estetis), sportif, tabah, terbuka, tertib. Individu juga memiliki kesadaran 
Konfrontasi: Jurnal Kultur, Ekonomi dan Perubahan Sosial, 4 (1) Januari 2017, 63-78

P-ISSN: $1410-881 X$ (Print)

Wiwin Luqna Hunaida, Guru Berkarakter Untuk Pendidikan Karakter

DOI: -

http://www.konfrontasi.net/index.php/konfrontasi2

untuk berbuat yang terbaik atau unggul, dan individu juga mampu bertindak sesuai potensi dan kesadarannya tersebut.

Guru akan membantu membentuk watak peserta didik. Hal ini men- cakup keteladanan bagaimana perilaku guru, cara guru berbicara atau menyampaikan materi, bagaimana guru bertoleransi, dan berbagai hal terkait lainnya.Agar guru mampu menyelenggarakan pendidikan dan pembelajaran yang memungkinkan untuk menanamkan karakter pada peserta didiknya, maka diperlukan sosok guru yang berkarakter. Guru yang berkarakter adalah guru yang tidak hanya mampu mentransfer pengetahuan ( transfer of knowledge), tetapi dia juga mampu menanamkan nilai-nilailuhur yang diperlukan oleh oleh siswanya dalam menjalani kehidupan sehari-hari ditengah masyara- kat yang majemuk.

Adapun nilai-nilai karakter yang harus dimiliki oleh guru dalam membangun insan yang berkarakter kuat, mulia dan cerdas antara lain:

1.) Komitmen

Komitmen didefinisikan sebagai sebuah tekad yang mengikat dan melekat pada seorang pendidik (guru) untuk melakukan tugas dan tanggung jawabnya sebagai pendidik. Adapun indikator guru yang memiliki komitmen tinggi adalah: Memiliki ketajaman visi; Rasa memiliki (sense of belonging), dan Bertanggung jawab (sense of responsibility).

2.) Kompeten

Kompeten adalah kemampuan seorang pendidik dalam menye- lenggarakan pembelajaran (mengajar dan mendidik) dan kemam- puan memecahkan berbagai masalah dalam rangka mencapai tujuan pendidikan.

Adapun indikator guru yang berkompeten adalah: Senantiasa mengembangkan diri; Ahli dibidangnya; Menjiwai profesinya, dan Memiliki kompetensi pedagogik,kepribadian, sosial dan profesional.

\section{3.) Kerja keras}

Guru yang selalu bekerja keras dapat didefinisikan sebagai ke- mampuan mencurahkan atau mengerahkan seluruh usaha dan kesungguhan, potensi yang dimiliki sampai akhir masa suatu urusan hingga tujuan tercapai. Adapun indikator guru yang selalu bekerja keras adalah:Bekerja ikhlas dan sungguh-sungguh; Bekerja melebihi target, dan Produktif.

4.) Konsisten

Guru yang konsisten adalah guru yang memiliki kemampuan melakukan sesuatu dengan istiqomah, ajeg, fokus, sabar, dan ulet serta melakukan perbaikan yang terus menerus. Adapun indikator guru yang selalu konsisten adalah: memiliki prinsip (istiqomah), tekun dan rajin, sabar dan ulet serta fokus.

5.) Kesederhanaan

Guru harus bersikap sederhana, artinya guru memiliki kemam- puan mengaktualisasikan sesuatu secara efektif dan efisien. Indikator guru yang bersikap sederhana adalah: guru yang bersa- haja, tidak mewah, tidak berlebih-lebihan, dan tepat guna.

6.) Kedekatan

Kedekatan yang dimaksudkan adalah kemampuan guru berinte- raksi secara dinamis dalam jalinan emosional antara guru dan peserta didik dalam rangka mencapai tujuan pembelajaran. Indi- kator kedekatan guru adalah: perhatian pada siswa (student centered); learning centered; dan terjalinnya hubungan emosional yang harmonis.

7.) Pelayanan maksimal

Guru seharusnya secara proaktif melayani siswa, maksudnya ada- lah kemampuan guru untuk membantu atau melayani atau me- menuhi kebutuhan peserta didiknya agar potensi 
Konfrontasi: Jurnal Kultur, Ekonomi dan Perubahan Sosial, 4 (1) Januari 2017, 63-78

P-ISSN: $1410-881 X$ (Print)

Wiwin Luqna Hunaida, Guru Berkarakter Untuk Pendidikan Karakter

DOI: -

http://www.konfrontasi.net/index.php/konfrontasi2

mereka dapat diberdayakan secara optimal. Adapun guru yang melayani dengan maksimal indikatornya adalah: dipenuhinya standar pelayanan minimal; kepuasan; cepat dan tanggap dengan segala perma- salahan yang sedang dihadapi siswa; pelayanan cepat; dan pro- aktif.

8.) Cerdas

Cerdas yang dimaksud bukan hanya cerdas secara intelektual tetapi guru juga harus cerdas secara emosional dan psiritual. Guru yang cerdas semacam ini memiliki ciri-ciri sebagai berikut:

a. Kemampuan cepat mengerti dan memahami, tanggap, tajam dalam menganalisis dan mampu mencari alternatif-alternatif solusi; serta mampu memecahkan masalah (cerdas secara inte- lektual).

b. Kemampuan memberikan makna/nilai terhadap berbagai aktivitas yang dilakukan sehingga hasilnya optimal (cerdas secara emosi dan spiritual).

Indikator dari guru yang cerdas adalah: responsif, analitis, inovatif, solutif, dan mewarnai berbagai aktivitas yang dila- kukan.

Terkait dengan pembahasan tentang guru berkarakter, perlu kita simak apa yang telah dipaparkan oleh Yusron Aminullah,24 dalam memotret sosok guru ke dalam kategori wajib, sunnah, makruh, mubah dan haram. Mari secara jujur menilai diri masing-masing layak dimasukkan dalam kategori mana:

> Guru Wajib: Guru yang keberadaannya sangat dibutuhkan oleh siswa dan sekolah. Indikatornya adalah:

- Jika guru ini tidak ada, murid dan sekolah akan kehilangan.

- Cara mengajarnya profesional.

- Sulit mencari gantinya.

- Sosok yang menjadi panutan.

- Selalu memelihara energi positif.

Mampukah kita setiap hari meningkatkan kualitas diri sehingga menjadi guru yang berkategori Wajib?

$>$ Guru Sunnah: adalah guru yang keberadaannya sangat dibutuhkan oleh murid dan sekolah, namun tidak satu-satunya. Indikatornya:

- Jika guru ini tidak ada, murid dan sekolah akan kehilangan.

- Cara mengajarnya profesional.

- Cara hidupnya dapat menjadi teladan.

- Tapi tidak sulit mencari gantinya karena ada beberapa guru lain yang seperti dirinya.

- Sosok yang menjadi panutan.

- Selalu memelihara energi positif.

Kita jujur menilai, Guru Sunnah, kualitasnya sedikit di bawah guru wajib. Dan mampukah kita setiap hari meningkatkan kualitas diri sehingga menjadi guru yang kategori Guru sunnah?

Guru Makruh: Guru yang keberadaannnya dianggap tidak penting oleh siswa dan sekolah, bahkan bisa disebut menjadi beban, baik karena performance-nya maupun sifat-sifatnya. Indikatornya:

- Jika guru tidak ada, murid dan sekolah justru senang, karena tidak membuat repot murid dan sekolah

- Cara mengajarnya dibawah standar.

- Cara hidupnya tidak dapat menjadi teladan.

- Tidak sulit mencari gantinya, karena banyak guru lain yang kualitasnya dia atas guru tipe ini. 
- Sosok yang tidak menjadi panutan.

- Sering kali menunjukkan energi negatif.

Guru Mubah: Guru yang keberadaannya biasa-biasa saja. Ada dan tidaknya tidak diperhitungkan oleh guru dan siswa. Semuanya standar, tidak menonjol tapi juga tidak menjadi beban. Indikatornya:

- Guru yang tidak istimewa.

- Cara mengajarnya sangat pas-pasan.

- Cara hidupnya juga biasa-biasa, tidak bisa menjadi teladan.

- Tidak sulit mencari gantinya, karena banyak guru lain yang kualitasnya di atas guru tipe

- Hidup dalam energi negatif.

Guru Haram: guru yang kebeadaannya sangat tidak dibutuhkan oleh siswa dan sekolah. Indikatornya adalah:

- Guru semacam ini tidak mengajar dan tidak berada di sekolah.

- Cara mengajarnya tidak profesional.

- Cara hidupnya tidak bisa menjadi teladan.

- Sosok yang tidak layak menjadi panutan.

- Selalu memelihara dan menunjukkan energi negatif.

Kita jujur menilai, bahwa guru tipikal guru makruh, mubah dan haram sebaiknya tidak ada di sekolah, karena bisa diganti dengan guru lain yang kualitasnya lebih baik. Dan mampukah kita tiap hari meningkatkan kualitas diri sehingga kita tidak sampai masuk kedalam kategori Guru Makruh, Guru Mubah bahkan Guru Haram, na'udzu billah.

Kita memang sulit mengukur keberhasilan guru dalam mengajar seka- ligus mendidik dengan menggunakan parameter umum yang selama ini di gunakan untuk menilai kinerja SDM. Maklum guru bukanlah semata- mata karyawan suatu instansi Pemerintah Daerah yang kinerjanya bisa diukur dengan menggunakan absensi atau kinerja yang terpaku dalam jenjang birokrasi. Guru juga bukan pedagang yang bisa diukur ber- dasarkan laku atau tidaknya barang dagangannya dalam sehari. Akan tetapi guru mendidik manusia yang setara dengan dirinya. Kepada guru melekat nilai-nilai baik-buruk, wajar-tidak wajar. Sopan-tidak sopan, jujur atau berbohong dan seterusnya. Guru adalah salah satu pilar pen- jaga nilai. Ia menjadi salah satu penentu masa depan suatu bangsa.

Oleh karena itu, upaya-upaya yang seharusnya tercermin dalam perilaku guru dalam mensikapi peserta didiknya adalah sebagai berikut:

a. Berpenampilan menarik, terutama tampak pada penampilan wajah berseri-seri, selalu tersenyum dalam setiap bertemu dengan siswanya, apresiatif terhadap perkembangan positif dan prestasi yang di dapat oleh mereka. Kondisi ini mencerminkan pribadi guru yang memiliki inner beauty(kecantikan dari dalam diri guru).

b. Mampu berkomunikasi dengan baik. Ucapannya enak didengar, jelas (pesan tersampaikan dengan tepat), menyejukkan, memotivasi, dan memberikan inspirasi, walaupun dalam konteks tertentu guru bisa berkata tegas.

c. Semua aktivitasnya dilakukan dengan sepenuh hati. Perasaan dan emosi, bahkan secara spiritual guru melibatkan diri secara penuh dalam melakukan tugasnya, termasuk juga menyertakan doa untuk para peserta didiknya dalam setiap lantunan doa yang guru panjatkan.

d. Selalu memberikan pelayanan maksimal. Guru senantiasa peduli dan proaktif memberikan pelayanan kepada peserta didiknya dalam kondisi bagaimanapun. Guru 
Konfrontasi: Jurnal Kultur, Ekonomi dan Perubahan Sosial, 4 (1) Januari 2017, 63-78

P-ISSN: 1410-881X (Print)

Wiwin Luqna Hunaida, Guru Berkarakter Untuk Pendidikan Karakter

DOI: -

http://www.konfrontasi.net/index.php/konfrontasi2

semestinya dapat memilah dan menempatkan diri sebagai pribadi dan sebagai seorang guru ketika menghadapi peserta didiknya.Saling membantu demi keberhasilan dalam pembelajarannya.

\section{Penutup}

Mengakhiri pembahasan ini, dapatlah kita simpulkan bahwa membangun karakter dan watak bangsa melalui pendidikan adalah sebuah kenis- cayaan, dan tidak bisa ditunda, mulai dari lingkungan rumah tangga, sekolah dan masyarakat dengan meneladani para tokoh yang memang patut untuk dicontoh. Di lingkungan sekolah, guru, kepala sekolah dan tenaga kependidikan merupakan komunitas yang secara langsung akan menjadi teladan bagi para siswa. Untuk itu karakter yang kuat harusnya lebih dahulu dimiliki oleh komunitas tersebut, terutama guru karena mereka akan menjadi contoh nyata yang dapat disaksikan secara langsung oleh para siswanya. Melalui sentuhan dan keteladanan para guru yang berkarakter dan berakhlak mulia inilah diharapkan akan lahir generasi yang tangguh dalam menghadapi derasnya arus globalisasi dan peduli dengan kondisi masyarakat disekitarnya.

Dengan demikian, yang harus kita andalkan dari peran guru di masa kini dan mendatang adalah keteladanan dan kepemimpinannya dalam membawakan suasana belajar di kelas dan di luar kelas yang tidak hanya berorientasi pada penguasaan meteri semata. Guru seharusnya menjadi teladan, membimbing, dan mengarahkan tuntunan sikap dan akhlak mulia untuk membentuk kepribadian dan karakter yang kuat, sekaligus kemampuan-kemampuan teknis bagi para peserta didik. Karena itu, orientasi pendidikan kita haruslah mengutamakan aspek-aspek afektif dan psikomotorik, dan bukan kognitif yang dapat dicari sendiri oleh para peserta didik. Yang penting ada dalam diri setiap peserta didik adalah sikap, karakter dan motivasi yang kuat disertai kemampuan teknis untuk mencari, menemukan, mengumpulkan, memahami, dan menguasai sega- la informasi ilmu pengetahuan yang diperlukan dalam hidup, bekerja, dan untuk bertindak dalam meningkatkan kualitas hidup pribadi dan kualitas hidup bersama dalam masyarakat dan bangsa kita.

\section{Bibliografi}

Ahmad Barizi \& Muhammad Idris, Menjadi Guru Unggul: Bagaimana menciptakan pembelajaran yang produktif \& profesional (Yogya- karta: Ar-Ruzz Media, 2011)

Danim, Sudarwan \& Yunan Danim, Administrasi Sekolah \& Manajemen Kelas (Bandung: CV. Pustaka setia, 2011)

Dryden, Gordon dan Vos, Jeannete, Revolusi Cara Belajar, Terj. Word Translation service, (Bandung: kaifa, 2000)

Hamka Abdul Aziz. (2012). Karakter Guru Profesional (Jakarta: al Mawardi Prima), Cet.I

Koesoema A. Doni, Pendidikan Karakter (Jakarta: Grasindo, 2007).

M. Furqon Hidayatullah, Pendidikan karakter: Membangun Peradaban Bangsa (Surakarta: Yuma Pustaka, 2010)

Muchlas Samani dan Hariyanto, Konsep dan Model Pendidikan Karakter, (Bandung: PT. Remaja Rosdakarya, 2011).

Qomari Anwar, Nilai agama Sebagai Acuan Membangun Karakter Bangsa, (Jakarta: Makalah, 12 April 2010).

Sa'dun Akbar, Revitalisasi Pendidikan karakter di Sekolah Dasar, pidato pengukuhan guru besar dalam bidang ilmu pendidikan/pendidikan dasar fakultas Ilmu Pendidikan Universitas Negeri Malang, 8 Juni 2011. 
Konfrontasi: Jurnal Kultur, Ekonomi dan Perubahan Sosial, 4 (1) Januari 2017, 63-78

P-ISSN: 1410-881X (Print)

Wiwin Luqna Hunaida, Guru Berkarakter Untuk Pendidikan Karakter

DOI: -

http://www.konfrontasi.net/index.php/konfrontasi2

Tim Pakar Yayasan Jati Diri Bangsa, Pendidikan Karakter di Sekolah: Dari Gagasan ke Tindakan, (Jakarta: PT. Gramedia, 2011).

Timothy Wibowo, "Pentingnya Pendidikan Karakter Dalam Dunia Pendi- dikan", http://www.pendidikankarakter.com.

Yusron Aminullah, Mindset Pembelajaran: 10 langkah mendidik siswa secara kreatif dan humanis (Bandung: Nuansa, 2011)

, "Pendidikan Karakter", http://kabar-pendidikan.blogspot. com.

, Pendidikan Karakter Berpusat Pada Hati (Jakarta: Al- Mawardi Prima, 2012). 